\title{
Synthesis and characterization of bio-based quaternary ammonium salts with gibberellate or L-tryptophanate anion
}

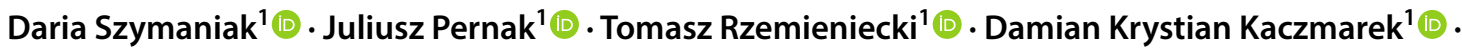 \\ Roman Andrzejak ${ }^{2}$ (1) $\cdot$ Tomasz Kosiada $^{2} \cdot$ Beata Janowska² ${ }^{2}$
}

Received: 30 May 2020 / Accepted: 10 August 2020 / Published online: 8 September 2020

(c) The Author(s) 2020

\begin{abstract}
Numerous biologically active acids can be transformed into an ionic form in a facile way and combined with appropriate quaternary ammonium cation to improve their application properties or biological activity. This study describes the synthesis of new quaternary ammonium salts with anions of gibberellic acid, a common plant growth regulator from the gibberellin group, or L-tryptophan, an important precursor of auxin biosynthesis. The surface-active tetrapentylammonium ion and natural substances such as acetylcholine, choline, and quinine were the sources of cations. Novel salts of gibberellic acid and L-tryptophan were obtained with high yields exceeding $97 \%$ as a result of the metathesis reaction or the neutralization of quaternary ammonium hydroxides. Phase transition temperatures, thermal and chemical stability, and solubility in solvents with different polarities were determined for all obtained salts. On the basis of studies regarding the influence of synthesized salts on the post-harvest longevity and quality of leaves of Convallaria majalis, it was established that the biological activity of the natural plant regulators in most cases was maintained. Therefore, it can be concluded that the conversion of the active substance into the form of a quaternary ammonium salt results in obtaining novel forms of plant growth regulators with favourable physicochemical properties while maintaining the efficacy of the biological active ingredients.
\end{abstract}

\section{Graphic abstract}

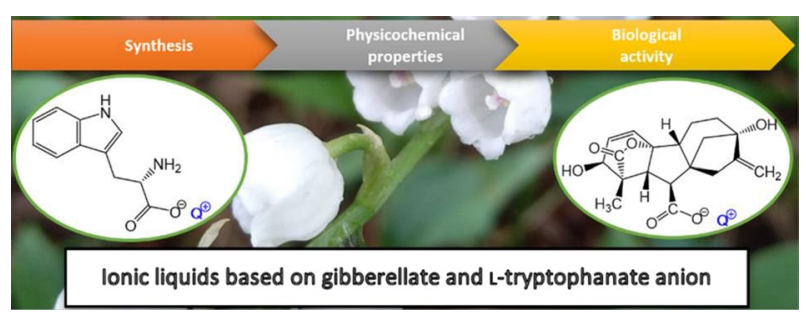

Keywords Bioorganic chemistry $\cdot$ Ionic liquids $\cdot$ Natural compounds $\cdot$ Phytochemistry $\cdot$ Plant growth regulators

Electronic supplementary material The online version of this article (https://doi.org/10.1007/s00706-020-02672-9) contains supplementary material, which is available to authorized users.

Juliusz Pernak

juliusz.pernak@put.poznan.pl

1 Faculty of Chemical Technology, Poznan University of Technology, ul. Berdychowo 4, 60-965 Poznan, Poland

2 Faculty of Horticulture and Landscape Architecture, Poznan University of Life Sciences, ul. Dąbrowskiego 159, 60-594 Poznan, Poland

\section{Introduction}

The ageing process of plant organs is the final phase of ontogenesis, during which irreversible changes that result in cell degradation and plant death are initiated [1]. Postharvest longevity is a species-specific trait, even at a varietal level; hence, the ageing of cut flowers occurs at different rates and is the main limitation for the marketing of many species [2]. The situation is similar for species grown as florist's greens. The longevity of the leaves of many species is unsatisfactory; hence, it is necessary to carry out additional 
post-harvest treatments, which are designed to extend their life after cutting. Ageing is closely associated with the action of growth regulators that accelerate (ethylene, abscisic acid) or delay (cytokinins, gibberellins) this process [3-8]. In the case of leaves, compounds from the cytokinin and gibberellin groups play a special role as they inhibit the degradation of proteins and chlorophyll, which directly contributes to delaying the ageing processes $[9,10]$.

Gibberellic acid (gibberellin $\mathrm{A}_{3}, \mathrm{GA}_{3}$ ) is the most commonly used regulator from the gibberellin group. This chemical affects shoot elongation [11], stimulates germination $[12,13]$ and extends the post-harvest longevity of flowers and florist's greens $[10,14]$. This compound, along with other gibberellins, is actively synthesized in plant tissues as well as in bacterial and fungal cells (e.g., in the case of the genus Fusarium) [15]. $\mathrm{GA}_{3}$ is a tetracyclic diterpenoid that contains eight chiral carbon atoms in its structure (Fig. 1). Due to the low efficiency of long-term fermentation processes, the market price of $\mathrm{GA}_{3}$ with technical purity can even reach $\$ 1000 / \mathrm{kg}$. As indicated in literature, gibberellic acid should be used at concentrations up to $100 \mathrm{ppm}$ to be effective $[14,16]$. Additional problems are associated with the low solubility of $\mathrm{GA}_{3}$ in water, which is $5 \mathrm{~g} \mathrm{dm}^{-3}$, and the instability of its aqueous solutions, which hinders the preparation of stable solutions used for agrotechnical operations $[15,17]$. Similar problems apply to the use of formulations containing auxin growth regulators, e.g., indole3-acetic acid (IAA) or indole-3-butyric acid (IBA), and other auxin-stimulating compounds, e.g., L-tryptophan (Trp) [17-19]. It is, therefore, necessary to search for new ways of applying plant growth regulators in new, persistent chemical forms that will allow overcoming these disadvantages. Several recent studies have focused on the introduction of active substances from the group of plant growth regulators in the form of potassium salts to chemically stabilize them.

In this study, we focused on the synthesis of new plant growth regulators in the form of quaternary ammonium salts. Natural cations such as choline and acetylcholine (both present in the human body) as well as cations derived from quinine (a plant alkaloid used to treat malaria) have been combined with gibberellic acid to increase its biological activity. The selection of these counter ions allowed us to

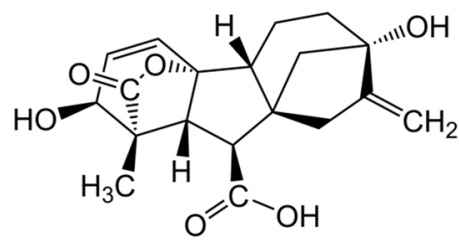

$\mathrm{GA}_{3}$

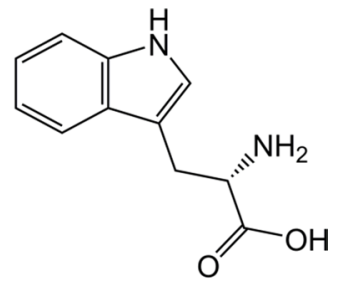

Trp
Fig. 1 Structures of gibberellic acid $\left(\mathrm{GA}_{3}\right)$ and L-tryptophan (Trp) obtain environmentally friendly salts. Whereas, L-tryptophan was combined with a synthetic tetrapentylammonium cation, since the salt thus obtained was characterized by the greatest chemical stability under aerobic conditions. Salts with L-tryptophanate anion and cations of natural origin degraded faster, which was considered highly undesirable in biological applications. The chemical structures of both gibberellate and L-tryptophanate anions are prone to decomposition, thus it was important to determine the thermal and chemical stability of the obtained salts. Since the new forms of both active ingredients were expected to possess more favourable physicochemical properties compared to acidic forms of $\mathrm{GA}_{3}$ an L-tryptophan (e.g., ready solubility in water and better thermal stability), we additionally evaluated the products' effect on the prolongation of post-harvest longevity of lily of the valley leaves ( $C$. majalis) to confirm that that the introduction of organic cations does not hinder the biological properties of the active ingredients.

\section{Results and discussion}

\section{Synthesis}

Quaternary ammonium salts (Table 1) with selected organic cations and anions from the group of plant growth regulators (Fig. 1) were obtained using two methods. Salts with choline (1) and acetylcholine (2) cations were obtained as a result of a metathesis reaction using a potassium salt of gibberellic acid in methanol (Scheme 1, method I). Salts with 1-ethylquinine (3), 1-dodecylquinine (4), and tetrapentylammonium (5) cations were obtained in a two-step reaction. In the first stage, the bromide anion was exchanged with a hydroxyl ion using an ion exchange resin, followed by a neutralization reaction with gibberellic acid or L-tryptophan in methanol (Scheme 1, method II). The methodology of synthesis and purification allowed us to obtain products with high yields, exceeding $90 \%$. The obtained products were stored in the presence of a drying agent $\left(\mathrm{P}_{4} \mathrm{O}_{10}\right)$. The results of elemental analysis confirmed the high purity the obtained compound (Table S1 in Electronic Supplementary Material).

The obtained salts were solids with melting points ranging from 96 to $136{ }^{\circ} \mathrm{C}$. The exception was the salt with the L-tryptophanate anion (5), which was a high-viscosity liquid at $25{ }^{\circ} \mathrm{C}$. This observation allowed us to classify $\mathbf{1 , 4}, \mathbf{4}$, and $\mathbf{5}$ as ionic liquids (ILs). The melting points for salts $\mathbf{2}$ and 3 were above the threshold of $100{ }^{\circ} \mathrm{C}$, which did not allow them to be classified as ILs.

The phase transitions and thermal stability of the obtained salts were determined by differential scanning calorimetry (DSC) or thermal gravimetric analysis (TGA). The results are presented in Table 1. In the studied temperature range, only the glass transition temperature $\left(T_{\mathrm{g}}\right)$ was observed, 
Table 1 Synthesized quaternary ammonium salts

\begin{tabular}{|c|c|c|c|c|c|c|c|}
\hline Salt & Cation & Anion & Yield/\% & $T_{\mathrm{m}} /{ }^{\circ} \mathrm{C}$ & $T_{\mathrm{g}} /{ }^{\circ} \mathrm{C}$ & $T_{\text {onset } 5 \%} /{ }^{\circ} \mathrm{C}$ & $T_{\text {onset50\% }} /{ }^{\circ} \mathrm{C}$ \\
\hline 1 & & $\mathrm{GA}_{3}^{-}$ & 98 & $100-102$ & 78 & 170 & 236 \\
\hline 2 & & $\mathrm{GA}_{3}^{-}$ & 97 & $133-136$ & 110 & 180 & 252 \\
\hline 3 & & $\mathrm{GA}_{3}^{-}$ & 99 & 109-112 & - & 175 & 285 \\
\hline 4 & & $\mathrm{GA}_{3}^{-}$ & 99 & $101-106$ & - & 219 & 315 \\
\hline 5 & & $\operatorname{Trp}^{-}$ & 98 & - & 10 & 190 & 211 \\
\hline $\mathrm{GA}_{3}$ & - & - & - & 229 & - & 243 & 298 \\
\hline $\operatorname{Trp}$ & - & - & - & 286 & - & 277 & 305 \\
\hline
\end{tabular}

$T_{\mathrm{m}}$ melting point, $T_{\mathrm{g}}$ glass transition temperature, $T_{\text {onset } 5 \%}$ decomposition temperature of $5 \%$ sample, $T_{\text {onset } 50 \%}$ decomposition temperature of $50 \%$ sample

Method I: Anion exchange

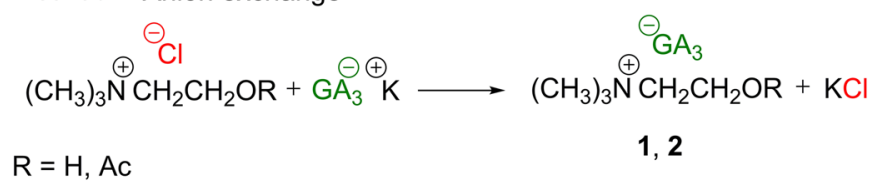

Method II: Neutralization of prepared hydroxide
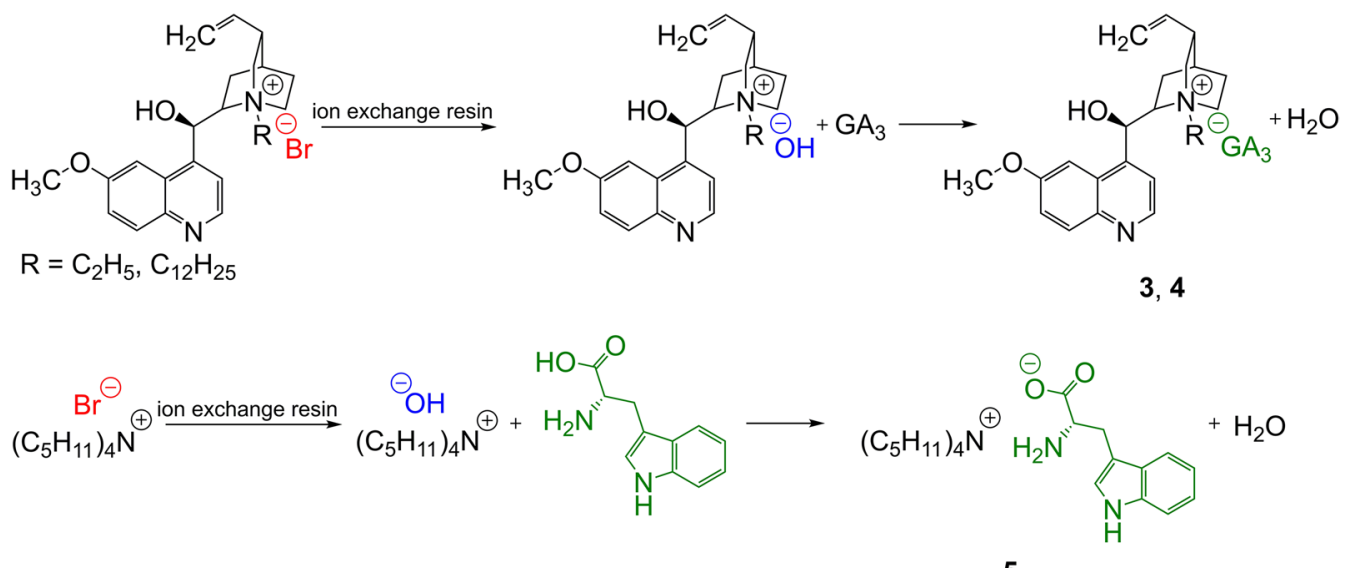

which depended on the chemical structure. Salts characterized by structurally "simple" cations exhibited $T_{\mathrm{g}}$. Moreover, the glass transition temperature is associated with the strong cation-anion interaction and the formation of additional hydrogen bonds [20]. This hypothesis was also confirmed in our studies, as ILs 1, 2, and $\mathbf{5}$ were characterized by the occurrence of a glass transition temperature, while salts with a more complex cation (3 and $\mathbf{4}$ ) did not exhibit this phase transition. Furthermore, the conversion of $\mathrm{GA}_{3}$ into an organic salt caused a decrease in thermal stability ( $T_{\text {onset5\% }}$ and $T_{\text {onset50\% }}$ ). The presence of an ionic bond in the obtained salts 1-3 resulted in a decrease in the $T_{\text {onset } 50 \%}$ in the range of $13-62{ }^{\circ} \mathrm{C}$ relative to $\mathrm{GA}_{3}\left(T_{\text {onset50\% }}=298{ }^{\circ} \mathrm{C}\right)$. It can, therefore, be assumed that the presence of an ionic 
bond increases the resistance to thermal decomposition [21]. Different behaviour was observed for compounds with the L-tryptophanate anion. Salt 5 exhibited lower thermal stability than pure L-tryptophan $\left(T_{\text {onset } 50 \%}=305^{\circ} \mathrm{C}\right)$ by $94{ }^{\circ} \mathrm{C}$, which may indicate a different mechanism of decomposition of salts with the amino acid anion [22].

The structures of the newly obtained salts were confirmed by nuclear magnetic resonance spectroscopy and FT-IR spectroscopy. NMR and FT-IR spectra for salts 1-5 with corresponding descriptions are provided in the ESM (Figs. $\mathrm{S} 1-\mathrm{S} 15$ ). Characteristic signals derived from $\mathrm{GA}_{3}$ (doublet of doublets at 5.70-5.90 ppm and doublet at 6.20-6.40 ppm) and Trp (signals at 2.95 and $3.26 \mathrm{ppm}$ ) observed in the ${ }^{1} \mathrm{H}$ NMR spectra confirm the presence of the appropriate anions in the obtained salts. Significant differences in chemical shifts derived from the carboxyl group were observed in the ${ }^{13} \mathrm{C}$ NMR spectrum. Compared to that chemical shift for $\mathrm{GA}_{3}$, the differences were $1.19 \mathrm{ppm}$ for $\mathbf{1}, 0.87 \mathrm{ppm}$ for $\mathbf{2}, 1.31 \mathrm{ppm}$ for $\mathbf{3}$, and $1.22 \mathrm{ppm}$ for $\mathbf{4}$. The conversion of L-tryptophan into an IL resulted in a change in the chemical shift of the signal associated with the carbon atom in the carboxyl group from 172.61 to $184.26 \mathrm{ppm}$.

\section{Solubility}

The synthesized ILs were tested in terms of their solubility in ten solvents, which were ordered from the highest (9.0) to the lowest $(0.0)$ value of the polar coefficient according to Snyder. The test results summarized in Table 2 indicate that salts 1-3 and $\mathbf{5}$ are characterized by good solubility in the most polar solvents (water, methanol, DMSO) and that salt $\mathbf{4}$ is characterized by a lack of solubility in water. Gibberellic acid is poorly soluble in water [17]; therefore, the obtained results indicate that its transformation into an ionic form can significantly facilitate the preparation of dosage forms in the form of aqueous solutions. Depending on the structure of the cation in the quaternary ammonium salt, the solubility of the compounds in organic solvents varies. The hydrophilic structure of acetylcholine limits the solubility of salt $\mathbf{2}$ in less polar solvents than DMSO, while salt $\mathbf{1}$ with the choline cation does not dissolve in isopropanol and less polar solvents. Cations with less hydrophilic properties allow salts 3-5 to dissolve in acetone and isopropanol. Therefore, comparing the solubility of the obtained salts with gibberellic acid and L-tryptophan, it can be indicated that the conversion of these compounds into ionic form has a positive effect on solubility in polar solvents.

Additionally, salt $\mathbf{4}$ exhibited good solubility in chloroform while maintaining low affinity for other weakly polar solvents: ethyl acetate, toluene and hexane. This fact confirms the hypothesis that quaternary ammonium salts dissolve better in solvents with higher dielectric constants $\left(\varepsilon_{\mathrm{r}}\right.$ of chloroform $=4.8$ ) than in solvents with a lower value of this parameter $\left(\varepsilon_{\mathrm{r}}\right.$ of toluene $=2.4, \varepsilon_{\mathrm{r}}$ of hexane $\left.=1.9\right)$ [23] . The synthesized bio-based IL 5 also exhibited a high affinity for highly polar systems.

\section{Chemical stability}

The chemical stability of aqueous solutions of gibberellic acid, L-tryptophan and the obtained salts $\mathbf{1 , 2}$ and $\mathbf{5}$ was tested at $80{ }^{\circ} \mathrm{C} .{ }^{1} \mathrm{H}$ and ${ }^{13} \mathrm{C}$ NMR spectra of the salts were obtained before and after heating. Comparison of the NMR spectra allowed observation and identification of the degradation products, as described in Figs. S16-S21 in the ESM.

Analysis of the ${ }^{1} \mathrm{H}$ NMR spectra of $\mathrm{GA}_{3}$ after heating indicated the disappearance of the signal from hydrogen atoms in the cyclohexene ring $(6.38-6.35 \mathrm{ppm}$, $5.89-5.85 \mathrm{ppm}$, and $4.00-3.99 \mathrm{ppm}$ as well as the signal at $3.23-3.20 \mathrm{ppm}$, which is associated with the hydrogen atom in the cyclopentane ring). Furthermore, the characteristic signals from the decomposition of $\mathrm{GA}_{3}$ have been described in the literature [24, 25]: 5.08 ppm (epiallogibberic acid), 4.71-4.69 and 3.95-3.89 ppm (allogibberic acid), 4.20-4.19 ppm (gibberic acid), 2.46-2.20 ppm and 7.25-6.96 ppm (gibberic acid, epigibberic acid,

Table 2 Solubility of prepared salts at $25^{\circ} \mathrm{C}$

\begin{tabular}{|c|c|c|c|c|c|c|c|c|c|c|}
\hline Salt & $\begin{array}{l}\text { Water } \\
9.0^{\mathrm{a}}\end{array}$ & $\begin{array}{l}\text { Methanol } \\
6.6\end{array}$ & $\begin{array}{l}\text { DMSO } \\
6.5\end{array}$ & $\begin{array}{l}\text { Acetonitrile } \\
6.2\end{array}$ & $\begin{array}{l}\text { Acetone } \\
5.1\end{array}$ & $\begin{array}{l}\text { Isopropanol } \\
4.3\end{array}$ & $\begin{array}{l}\text { Ethyl acetate } \\
4.3\end{array}$ & $\begin{array}{l}\text { Chloroform } \\
4.1\end{array}$ & $\begin{array}{l}\text { Toluene } \\
2.3\end{array}$ & $\begin{array}{l}\text { Hexane } \\
0.0\end{array}$ \\
\hline 1 & + & + & + & \pm & + & - & - & - & - & - \\
\hline 2 & + & + & + & - & - & - & - & - & - & - \\
\hline 3 & + & + & + & - & + & + & - & - & - & - \\
\hline 4 & - & + & + & - & + & + & - & + & - & - \\
\hline 5 & + & + & + & \pm & + & \pm & - & - & - & - \\
\hline $\mathrm{GA}_{3}$ & - & + & \pm & - & + & - & - & - & - & - \\
\hline $\operatorname{Trp}$ & - & - & - & - & - & - & - & - & - & - \\
\hline
\end{tabular}

+ Soluble, \pm limited solubility, - not soluble

${ }^{\text {a }}$ Snyder polarity index 
allogibberic acid, epiallogibberic acid). In contrast, the disappearance of signals from carbon atoms in the cyclohexene ring was visible (92.48 and $70.53 \mathrm{ppm}$ ) in the ${ }^{13} \mathrm{C}$ NMR spectra. Moreover, after decomposition, additional signals from carboxyl groups in the structure of $\mathrm{GA}_{3}$ decomposition products appeared in the carbon spectra (179.64, 178.04 and $175.68 \mathrm{ppm})$.

Analogous observations were noted in the ${ }^{1} \mathrm{H}$ and ${ }^{13} \mathrm{C}$ NMR spectra of salts $\mathbf{1}$ and $\mathbf{2}$; the disappearance of signals from the gibberellin anion and the appearance of signals from its degradation products were visible. In the spectrum of salt $\mathbf{2}$, signals originating from the degradation products of the acetylcholine cation to choline and acetic acid $\left({ }^{1} \mathrm{H}\right.$ NMR, 3.47 and $3.39 \mathrm{ppm} ;{ }^{13} \mathrm{C}$ NMR, 180.00, $69.03,57.09$ and $21.96 \mathrm{ppm}$ ) were also visible after heating in addition to signals from the $\mathrm{GA}_{3}$ anion degradation products, as shown in Fig. 2. The conversion of gibberellic acid to ions did not increase its chemical stability.

In the case of L-tryptophan, no shift of resonance signals was observed in the ${ }^{1} \mathrm{H}$ and ${ }^{13} \mathrm{C}$ NMR spectra, which confirms the stability of L-tryptophan under the given conditions (Figs. S22, S23 in ESM). In the case of salt 5, the chemical shift changed in the NMR spectra (Figs. S24, S25 in ESM), indicating the instability of this compound. In the ${ }^{1} \mathrm{H}$ NMR spectrum of salt 5 after heating, a decrease in signal integration and intensity by more than $20 \%$ as well as shifts in resonance signals in the ${ }^{1} \mathrm{H}$ and ${ }^{13} \mathrm{C}$ NMR spectra by $\sim 0.1 \mathrm{ppm}$ and $1 \mathrm{ppm}$, respectively. The observed differences clearly indicate a change in the chemical structure of salt $\mathbf{5}$ after heating. The conversion of L-tryptophan to ion reduced its chemical stability. A comparison of the ${ }^{1} \mathrm{H}$ NMR spectra of salt $\mathbf{5}$ and its degradation products is shown in Fig. 3.

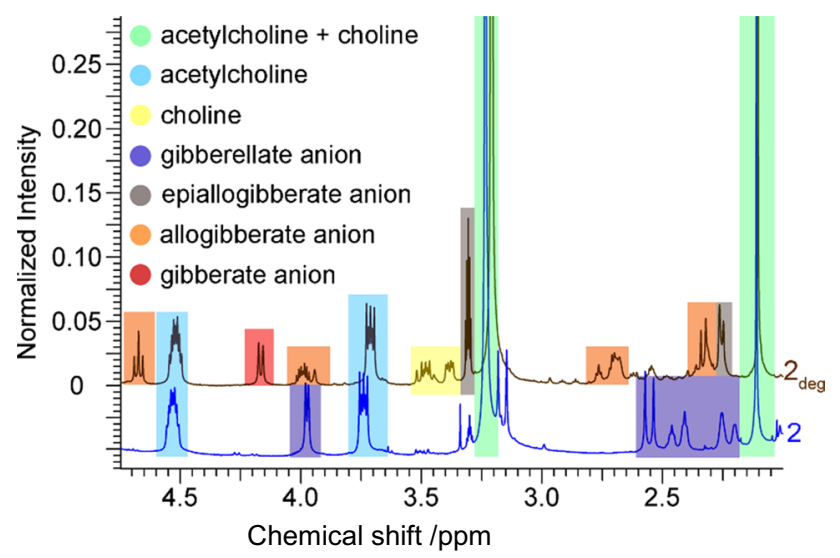

Fig. 2 Comparison of the ${ }^{1} \mathrm{H}$ NMR spectra of salt $\mathbf{2}$ and its degradation products $\left(\mathbf{2}_{\mathrm{deg}}\right)$

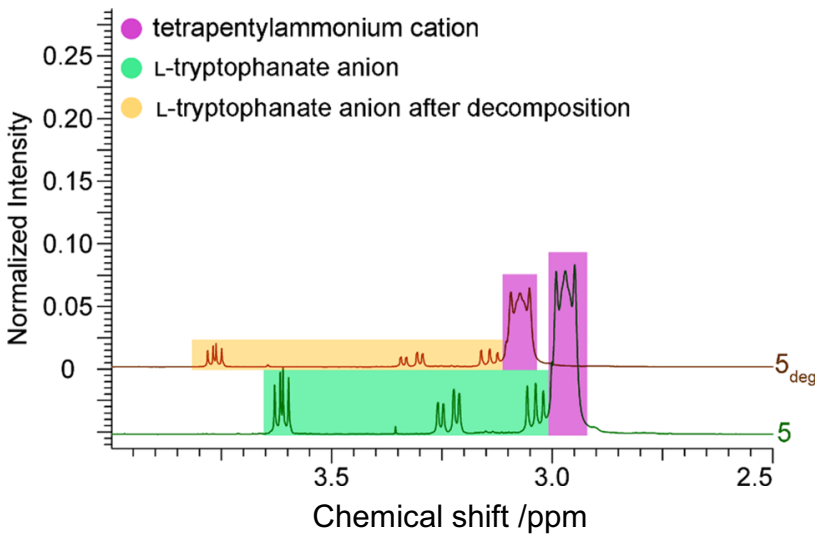

Fig. 3 Comparison of the ${ }^{1} \mathrm{H}$ NMR spectra of salt 5 and its degradation products $\left(\mathbf{5}_{\mathbf{d e g}}\right)$

\section{Biological activity}

C. majalis was the test plant in the post-harvest analysis of leaf longevity. The obtained results are presented in Fig. 4.

The post-harvest longevity of C. majalis leaves depended both on the type of growth regulator used and its concentration (Fig. 4). Analysis of the obtained results indicated that leaves in the control sample were the least durable comparing with salts $\mathbf{1}-\mathbf{4}$ and $\mathrm{GA}_{3}$. The most durable leaves were obtained after using $\mathrm{GA}_{3}$ at the tested concentrations and salt $\mathbf{1}$ at $100 \mathrm{ppm}$. Comparing the efficiency of salts with gibberellin anions (1-4), it was found that their effect was significantly more potent when used at a concentration of $100 \mathrm{ppm}$. The exception was salt $\mathbf{3}$, which showed higher activity when used at a concentration of $50 \mathrm{ppm}$. This phenomenon may be associated with the unique interactions of the quinine cation, which is not blocked by the presence of a long alkyl chain. In addition, it was observed that the introduction of the acetyl group into the choline cation limited the preserving effect of the compound at both tested concentrations (Fig. 4a).

The available literature reports do not provide an answer to the question regarding whether tryptophan can have a positive effect on the post-harvest longevity of florist's greens. After using L-tryptophan and salt 5 in an analogous manner to that of the gibberellic acid derivatives, it was found that the most durable leaves were obtained in the control combination, regardless of the concentration used. Compared to that of control leaves, the post-harvest leaf longevity after using L-tryptophan and salt 5 at 0.1 and $1.0 \mathrm{ppm}$ was $8-12 \%$ lower, which indicates that salt 5 acts analogously to L-tryptophan. The use of higher concentrations of both compounds decreased the leaf longevity by 20-33\%, indicating their phytotoxicity (Fig. 4b).

The lowest chlorophyll $a+b$ content in the ageing leaves of $C$. majalis was found in the control leaves. 

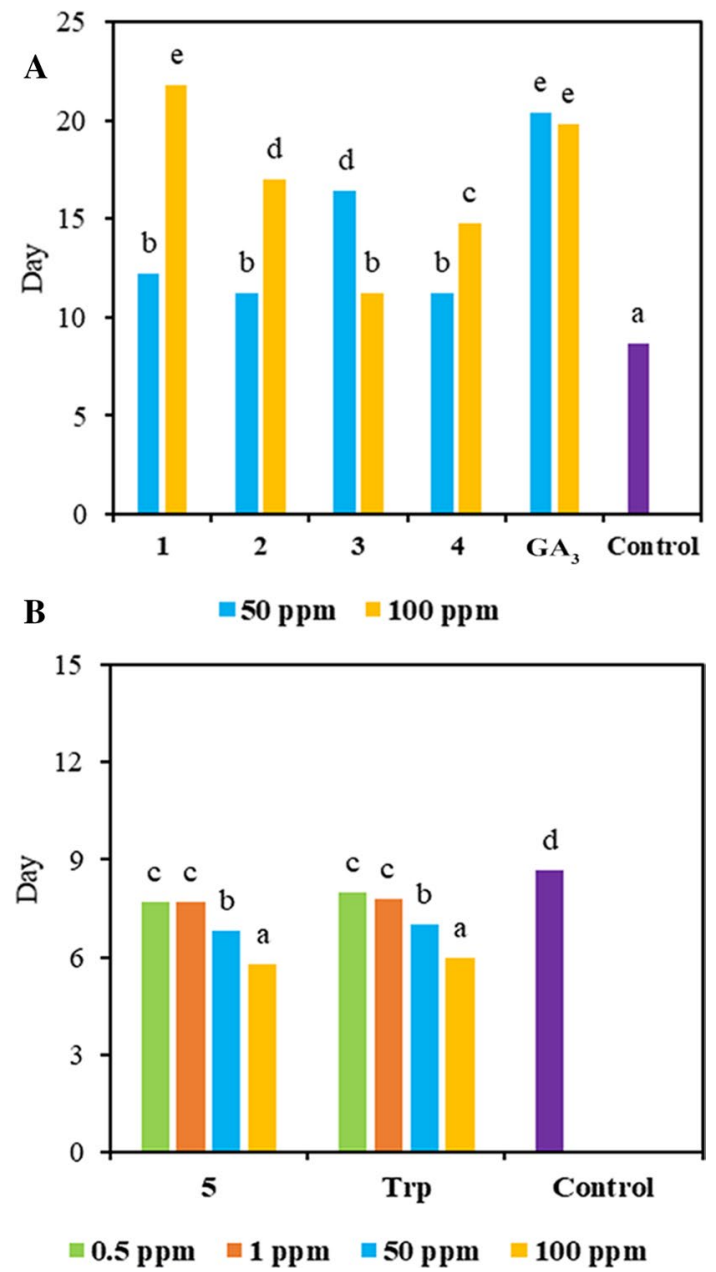

Fig. 4 Post-harvest longevity of $C$. majalis leaves conditioned in solutions of $\mathrm{GA}_{3}$ and salts 1-4 with the gibberellate anion (b) and salt 5 with the L-tryptophanate anion (b); the means followed by the same letter do not differ significantly at $\alpha=0.05$

Solutions of $\mathrm{GA}_{3}$ and salts 1-4 significantly inhibited the degradation of chlorophyll in the leaves at both concentrations, with no significant differences between the concentrations used and no differences in the effects of $\mathrm{GA}_{3}$ and salts 1-4 (Fig. S26A in ESM). Moreover, both gibberellic acid and salts 1-4 used in the studies inhibited protein degradation in the leaves at both tested concentrations (Fig. S26B in ESM). A similar effect in terms of delaying protein ageing after application of $\mathrm{GA}_{3}$ was observed in the leaves of Zantedeschia aethiopica and Zantedeschia elliottiana [26]. Despite a significant modification of the plant growth regulators, their metabolic activity remained unchanged, and the majority of the obtained compounds had a positive effect on the post-harvest leaf longevity.

\section{Conclusion}

The use of two highly effective methods of synthesis allowed the transformation of gibberellic acid and L-tryptophan into quaternary ammonium salts. Three out of five obtained compounds can be classified as ionic liquids. Based on the spectral analysis, it was confirmed that during synthesis, neither gibberellate anions nor L-tryptophanate anions are degraded. After conversion to the ionic form, the resulting products exhibited affinity for protic (methanol, isopropanol) and highly polar (DMSO) solvents.

Based on the conducted chemical stability tests, it can be concluded that the transformation of gibberellic acid to the ionic form does not increase its stability. In the case of L-tryptophan, it has been observed that converting it into an anion reduces its stability. The degradation of the obtained compounds is consistent with the natural metabolic pathways for plant regulators.

Quaternary ammonium salts with gibberellate anions extended the post-harvest longevity of $C$. majalis leaves. A more than twofold increase in leaf longevity was achieved after using choline gibberellate at a concentration of $100 \mathrm{ppm}$ and gibberellic acid at the tested concentrations. The biological activity of the remaining salts was lower; however, after their application, the post-harvest longevity of the leaves was higher than that of the control leaves. However, the use of both L-tryptophan and tetrapentylammonium L-tryptophanate did not increase the post-harvest longevity, which was particularly apparent when these compounds were used at higher concentrations.

\section{Experimental}

Acetylcholine chloride (purity 99\%), bromoethane (purity 99\%), 1-bromododecane (purity 97\%), choline chloride (purity 99\%), Dowex-Monosphere 550A anion exchange resin, gibberellic acid (purity 90\%), L-tryptophan (purity 98\%), tetrapentylammonium bromide (purity 98\%), quinine (purity 99\%) were purchased in Sigma-Aldrich (Poznań, Poland). Potassium hydroxide (purity 99\%) and all solvents (methanol, acetonitrile, acetone, hexane, toluene, chloroform, isopropanol, DMSO and ethyl acetate) were purchased from Avantor (Gliwice, Poland). Deionized water with a conductivity $<0.1 \mu \mathrm{S} \mathrm{cm}^{-1}$, from demineralizer HLP Smart 1000 (Hydrolab, Poland) was used for solubility tests. All reagents and solvents were used without further purification.

The ${ }^{1} \mathrm{H}$ NMR spectra were recorded on Mercury 300 (Varian Inc.) and VNMR-S 400 MHz (Varian Inc.) 
spectrometers operating at $300 \mathrm{MHz}$ and $400 \mathrm{MHz}$, respectively, using TMS as the internal standard. The ${ }^{13} \mathrm{C}$ NMR spectra were obtained using the same instruments operating at 75 and $100 \mathrm{MHz}$, respectively. The elemental analyses (CHN) were performed using an Elementar Analyser Vario EL III at Adam Mickiewicz University, Poznan (Poland). Melting points of the obtained products were determined using MP90 Melting Point System (Mettler Toledo). The FT-IR spectra of the samples as $\mathrm{KBr}$ pellets were recorded on a spectrophotometer (IFS 66v/S, Bruker) from 4000 to $400 \mathrm{~cm}^{-1}$.

\section{Synthetic method of choline gibberallate and acetylcholine gibberellate}

Salts with choline and acetylcholine cations $(\mathbf{1}, \mathbf{2})$ were obtained using the metathesis reaction. To conduct the reaction, choline chloride or acetylcholine chloride $(0.05 \mathrm{M})$ was dissolved in $30 \mathrm{~cm}^{3}$ anhydrous methanol. A stoichiometric amount of potassium gibberellate was added to the solution. The reaction was carried out for 30 min at $25{ }^{\circ} \mathrm{C}$. The mixture was then cooled to $5{ }^{\circ} \mathrm{C}$, the inorganic salt was separated by filtration, and the solvent was evaporated using a vacuum evaporator.

Choline gibberallate $\left(1, \mathrm{C}_{24} \mathrm{H}_{35} \mathrm{NO}_{7}\right)$ Yield: $98 \% ;{ }^{1} \mathrm{H}$ NMR (300 MHz, $\left.\mathrm{CD}_{3} \mathrm{OD}\right): \delta=6.37(\mathrm{~d}, J=9.3 \mathrm{~Hz}, 1 \mathrm{H}), 5.85$ (dd, $\left.J_{1,2}=3.6 \mathrm{~Hz}, J_{1,3}=9.4 \mathrm{~Hz}, 1 \mathrm{H}\right), 5.15(\mathrm{~s}, 1 \mathrm{H}), 3.98-4.03(\mathrm{~m}$, $2 \mathrm{H}), 3.96(\mathrm{~d}, J=3.5 \mathrm{~Hz}, 1 \mathrm{H}), 3.48-3.52(\mathrm{~m}, 2 \mathrm{H}), 3.22(\mathrm{~s}$, $9 \mathrm{H}), 2.54(\mathrm{~d}, J=10.4 \mathrm{~Hz}, 1 \mathrm{H}), 2.43-2.51(\mathrm{~m}, 1 \mathrm{H}), 2.20-2.31$ $(\mathrm{m}, 1 \mathrm{H}), 1.65-2.02(\mathrm{~m}, 9 \mathrm{H}), 1.25(\mathrm{~s}, 3 \mathrm{H}) \mathrm{ppm} ;{ }^{13} \mathrm{C} \mathrm{NMR}$ (75 MHz, $\mathrm{CD}_{3} \mathrm{OD}$ ): $\delta=182.21,179.66,159.48,134.20$, 133.74, 106.67, 93.31, 78.99, 71.03, 69.19, 55.23, 54.88, 54.43, 52.15, 51.29, 46.44, 44.95, 39.96, 18.22, $15.17 \mathrm{ppm}$; FT-IR: $=\bar{v} 3346,3033,2967,2933,2875,1759,1476,1452$, 1398, 1381, 1351, 1329, 1298, 1226, 1162, 1130, 1102, $1050,1018,952,890,864,746,599,571 \mathrm{~cm}^{-1}$.

Acetylcholine gibberallate $\left(2, \mathrm{C}_{26} \mathrm{H}_{37} \mathrm{NO}_{8}\right)$ Yield: $97 \% ;{ }^{1} \mathrm{H}$ NMR (300 MHz, $\left.\mathrm{CD}_{3} \mathrm{OD}\right): \delta=6.37(\mathrm{~d}, J=9.3 \mathrm{~Hz}, 1 \mathrm{H}), 5.85$ $\left(\mathrm{dd}, J_{1,2}=3.6 \mathrm{~Hz}, J_{1,3}=9.4 \mathrm{~Hz}, 1 \mathrm{H}\right), 5.16(\mathrm{~s}, 1 \mathrm{H}), 4.49-4.57$ (m, 1H), 3.98-3.97 (d, J=3.6 Hz, 1H), 3.76-3.72 (m, 2H), $3.27-3.12(\mathrm{~m}, 9 \mathrm{H}), 2.55(\mathrm{~d}, J=10.5 \mathrm{~Hz}, 1 \mathrm{H}), 2.47-2.38(\mathrm{~m}$, $1 \mathrm{H}), 2.18-2.28(\mathrm{~m}, 1 \mathrm{H}), 2.11(\mathrm{~s}, 3 \mathrm{H}), 1.98-1.72(\mathrm{~m}, 9 \mathrm{H})$, 1.23 (s, 3H) ppm; ${ }^{13} \mathrm{C}$ NMR (75 MHz, $\left.\mathrm{CD}_{3} \mathrm{OD}\right): \delta=181.89$, 178.70, 159.09, 134.05, 133.55, 106.87, 93.06, 78.79, 70.68, 65.94, 58.98, 55.45, 54.78, 54.56, 51.99, 51.10, 46.04, 44.64, 39.79, 20.84, 18.06, $15.11 \mathrm{ppm}$; FT-IR: $=v 3416$, 3030, 2964, 2929, 2871, 1748, 1651, 1568, 1476, 1449, 1394, 1383, 1326, 1245, 1159, 1107, 1100, 1046, 1019, 945, $891,861,812,743,596,568,407 \mathrm{~cm}^{-1}$.

\section{General synthetic method of 1-ethylquinine gibberallate, 1-dodecylquinine gibberallate, tetrapentylammonium L-tryptophanate}

The synthesis of salts 3-5 was carried out in two stages. To conduct the synthesis, 1-alkylquinine bromides obtained analogously to the method described in the literature [27] and purified and commercial tetrapentylammonium bromide were used. In the first stage, 1-alkylquinine bromide or tetrapentylammonium bromide $(0.02 \mathrm{M})$ was dissolved in $30 \mathrm{~cm}^{3}$ anhydrous methanol and exchanged to a hydroxide salt using an anion exchange resin. The reaction was carried out for $30 \mathrm{~min}$ at $25^{\circ} \mathrm{C}$. The resin was then filtered under reduced pressure. A stoichiometric amount of gibberellic acid or L-tryptophan was added to the obtained hydroxide. The reaction was carried out for $1 \mathrm{~h}$ at $25^{\circ} \mathrm{C}$. Then, the solvent was removed using a rotary evaporator. The obtained salts were dried using a vacuum dryer at $40{ }^{\circ} \mathrm{C}$ for $48 \mathrm{~h}$.

1-Ethylquinine gibberallate $\left(3, \mathrm{C}_{41} \mathrm{H}_{50} \mathrm{~N}_{2} \mathrm{O}_{8}\right)$ Yield: $99 \% ;{ }^{1} \mathrm{H}$ NMR (400 MHz, DMSO- $\left.d_{6}\right): \delta=8.75(\mathrm{~d}, J=4.5 \mathrm{~Hz}, 1 \mathrm{H})$, 7.99 (d, $J=9.2 \mathrm{~Hz}, 1 \mathrm{H}), 7.73$ (d, $J=4.6 \mathrm{~Hz}, 1 \mathrm{H}), 7.46$ (dd, $\left.J_{1,2}=2.6 \mathrm{~Hz}, J_{1,3}=9.2 \mathrm{~Hz}, 1 \mathrm{H}\right), 7.30(\mathrm{~d}, J=2.6 \mathrm{~Hz}, 1 \mathrm{H})$, $6.51(\mathrm{~s}, 1 \mathrm{H}), 6.27(\mathrm{~d}, J=9.3 \mathrm{~Hz}, 1 \mathrm{H}), 5.82-5.70(\mathrm{~m}, 2 \mathrm{H})$, $5.13(\mathrm{~d}, J=17.3 \mathrm{~Hz}, 1 \mathrm{H}), 5.04-4.98(\mathrm{~m}, 2 \mathrm{H}), 4.60(\mathrm{~s}, 1 \mathrm{H})$, 4.25-4.16 (m, 1H), 3.97 (s, 3H), 3.95-3.87 (m, 2H), 3.83$3.81(\mathrm{~d}, J=3.3 \mathrm{~Hz}, 1 \mathrm{H}), 3.74-3.62(\mathrm{~m}, 2 \mathrm{H}), 3.43-3.31(\mathrm{~m}$, $2 \mathrm{H}), 3.06(\mathrm{~d}, J=10.3 \mathrm{~Hz}, 1 \mathrm{H}), 2.81-2.72(\mathrm{~m}, 1 \mathrm{H}), 2.25-2.31$ (m, 2H), 2.23-2.11 (m, 2H), 2.02-1.98 (m, 1H), 1.91-1.89 (m, 2H), 1.87-1.83 (m, 1H), 1.74-1.51 (m, 6H), 1.46-1.31 (m, 4H), $1.03(\mathrm{~s}, 3 \mathrm{H}) \mathrm{ppm} ;{ }^{13} \mathrm{C} \mathrm{NMR}\left(100 \mathrm{MHz}\right.$, DMSO- $\left.d_{6}\right)$ : $\delta=179.71,174.73,158.91,157.15,147.46,145.41,143.68$, $138.13,133.26,131.77,131.45,125.59,121.25,120.56$, $116.48,104.79,101.92,101.81,91.07,76.76,68.59,65.70$, 62.66, 58.91, 55.54, 55.03, 53.87, 53.17, 52.96, 51.98, $50.40,49.30,45.08,43.35,38.99,37.51,26.18,24.70$, 20.16, 16.71, 14.50, 8.20 ppm; FT-IR: $=$ v3370, 3278, 3038, 2968, 2937, 2878, 1758, 1659, 1622, 1576, 1510, 1454, $1431,1397,1379,1329,1240,1227,1161,1128,1102$, 1046, 1022, 996, 970, 944, 921, 889, 862, 828, 778, 745, $721,700,663,634,599,570,543,463,430,411 \mathrm{~cm}^{-1}$.

1-Dodecylquinine gibberallate $\left(4, \mathrm{C}_{51} \mathrm{H}_{70} \mathrm{~N}_{2} \mathrm{O}_{8}\right)$ Yield: $99 \%$; ${ }^{1} \mathrm{H}$ NMR (400 MHz, DMSO- $d_{6}$ ): $\delta=8.75(\mathrm{~d}, J=4.5 \mathrm{~Hz}$, $1 \mathrm{H}), 7.99(\mathrm{~d}, J=9.2 \mathrm{~Hz}, 1 \mathrm{H}), 7.71(\mathrm{~d}, J=4.5 \mathrm{~Hz}, 1 \mathrm{H}), 7.46$ $\left(\mathrm{dd}, J_{1,2}=2.5 \mathrm{~Hz}, J_{1,3}=9.2 \mathrm{~Hz}, 1 \mathrm{H}\right), 7.30(\mathrm{~d}, J=2.4 \mathrm{~Hz}, 1 \mathrm{H})$, $6.49(\mathrm{~s}, 1 \mathrm{H}), 6.25(\mathrm{~d}, J=9.3 \mathrm{~Hz}, 1 \mathrm{H}), 5.82-5.70(\mathrm{~m}, 2 \mathrm{H})$, $5.12(\mathrm{~d}, J=17.3 \mathrm{~Hz}, 1 \mathrm{H}), 5.04-4.96(\mathrm{~m}, 2 \mathrm{H}), 4.58(\mathrm{~s}, 1 \mathrm{H})$, 4.33-4.22 (m, 1H), $3.97(\mathrm{~s}, 3 \mathrm{H}), 3.95-3.89(\mathrm{~m}, 1 \mathrm{H}), 3.83(\mathrm{~d}$, $J=4.5 \mathrm{~Hz}, 1 \mathrm{H}), 3.74-3.66(\mathrm{~m}, 3 \mathrm{H}), 3.45-3.34(\mathrm{~m}, 2 \mathrm{H}), 3.06$ $(\mathrm{d}, J=10.2 \mathrm{~Hz}, 1 \mathrm{H}), 2.80-2.72(\mathrm{~m}, 1 \mathrm{H}), 2.31(\mathrm{~d}, J=16.2 \mathrm{~Hz}$, $1 \mathrm{H}), 2.25(\mathrm{~d}, J=10.2 \mathrm{~Hz}, 1 \mathrm{H}), 2.23-2.12(\mathrm{~m}, 2 \mathrm{H}), 1.97(\mathrm{~s}$, 1H), $1.93(\mathrm{~s}, 1 \mathrm{H}), 1.89-1.77(\mathrm{~m}, 4 \mathrm{H}), 1.73-1.51(\mathrm{~m}, 6 \mathrm{H})$, 
1.43-1.19 (m, 19H), $1.03(\mathrm{~s}, 3 \mathrm{H}), 0.88-0.84(\mathrm{t}, J=6.9 \mathrm{~Hz}$, $3 \mathrm{H}) \mathrm{ppm} ;{ }^{13} \mathrm{C}$ NMR $\left(100 \mathrm{MHz}, \mathrm{DMSO}-d_{6}\right): \delta=179.80$, $174.94,158.99,157.18,147.52,145.66,143.70,138.13$, $133.36,131.70,131.43,125.61,121.05,120.56,116.49$, $104.63,101.99,76.77,68.58,66.64,62.57,59.79,59.47$, $55.33,54.18,53.16,53.13,51.95,50.38,49.35,48.60$, $45.27,43.45,37.63,31.36,29.14,29.08,28.79,28.69$, $26.35,26.12,24.69,22.15,22.06,20.15,16.80,14.54$, 13.98 ppm; FT-IR: $=\bar{v} 3370,3270,3079,3037,2926,2854$, 1759, 1659, 1622, 1579, 1510, 1455, 1431, 1394, 1378, 1328, 1298, 1240, 1227, 1160, 1128,1101, 1046, 996, 970, $943,920,888,862,827,779,743,722,662,635,599,570$, $547,500,462,412 \mathrm{~cm}^{-1}$.

Tetrapentylammonium L-tryptophanate (5, $\mathrm{C}_{31} \mathrm{H}_{55} \mathrm{~N}_{3} \mathrm{O}_{2}$ ) Yield: 98\%; ${ }^{1} \mathrm{H}$ NMR (400 MHz, $\left.\mathrm{D}_{2} \mathrm{O}\right)$ : $\delta=7.73(\mathrm{~d}, J=7.9 \mathrm{~Hz}, 1 \mathrm{H}), 7.49$ (d, $J=8.3 \mathrm{~Hz}, 1 \mathrm{H}), 7.26-$ $7.20(\mathrm{~m}, 2 \mathrm{H}), 7.18-7.11(\mathrm{~m}, 1 \mathrm{H}), 3.64-3.59(\mathrm{~m}, 1 \mathrm{H}), 3.24$ $\left(\mathrm{dd}, J_{1,2}=4.6 \mathrm{~Hz}, J_{1,3}=14.6 \mathrm{~Hz}, 1 \mathrm{H}\right), 3.08-2.92(\mathrm{~m}, 9 \mathrm{H})$, $1.56-1.45(\mathrm{~m}, 8 \mathrm{H}), 1.39-1.19(\mathrm{~m}, 17 \mathrm{H}), 0.90(\mathrm{t}, J=7.1 \mathrm{~Hz}$, $12 \mathrm{H}) \mathrm{ppm} ;{ }^{13} \mathrm{C}$ NMR $\left(100 \mathrm{MHz}, \mathrm{D}_{2} \mathrm{O}\right): \delta=184.26,138.95$, $130.05,127.15,124.51,121.90,121.56,114.56,113.00$, $60.76,59.14,32.78,30.48,24.33,23.44,15.91 \mathrm{ppm}$; FT-IR: $=\bar{v} 3416,3228,2955,2922,2872,1575,1463,1385$, 1351, 1230, 1147, 1097, 1064, 1043, 1011, 915, 835, 739, $733,609,467,431 \mathrm{~cm}^{-1}$.

\section{Thermal analysis}

Thermal analysis was performed based on the method described in the literature [28, 29]. Thermal transition temperature was determined by DSC, with a Mettler Toledo Star ${ }^{\mathrm{e}}$ DSC1 (Mettler Toledo) unit, under nitrogen. Samples between 4.5 and $7.0 \mathrm{mg}$ were placed in aluminum pans and heated from 25 to $120^{\circ} \mathrm{C}$ at a heating rate of $10^{\circ} \mathrm{C} \mathrm{min}^{-1}$ and cooled with an intracooler at a cooling rate of $10^{\circ} \mathrm{C} \mathrm{min}-1$ to $-100{ }^{\circ} \mathrm{C}$ and then heated again to $120{ }^{\circ} \mathrm{C}$. Thermal gravimetric analysis was performed using a Mettler Toledo Star ${ }^{\mathrm{e}}$ TGA/DSC1 unit (Mettler Toledo) under nitrogen. Samples between 4.0 and $5.0 \mathrm{mg}$ were placed in aluminium pans and heated from 30 to $450{ }^{\circ} \mathrm{C}$ at a heating rate of $10{ }^{\circ} \mathrm{C} \mathrm{min}-1$.

\section{Solubility}

Water and nine popular organic solvents of varying polarity were selected for the solubility test and arranged in order of decreasing Snyder polarity index: water, 9.0; methanol, 6.6; DMSO, 6.5; acetonitrile, 6.2; acetone, 5.1; isopropanol, 4.3; ethyl acetate, 4.3; chloroform, 4.1; toluene, 2.3 and hexane, 0.0 . The solubility of the obtained salts in organic solvents was determined according to the methodology previously described in Vogel's Textbook of Practical Organic Chemistry [30]. The sample of salt $(0.1 \pm 0.0001 \mathrm{~g})$ was introduced into a specific volume of solvent. The analyses were performed at $25^{\circ} \mathrm{C}$. Depending on the volume of solvent used, three outcomes have been recorded: "ready solubility" applies to salts that dissolved in $1 \mathrm{~cm}^{3}$ of the solvent, "limited solubility" applies to compounds that dissolved in $3 \mathrm{~cm}^{3}$ of the solvent, and "low solubility" applies to ILs that did not dissolve in $3 \mathrm{~cm}^{3}$ of the solvent.

\section{Chemical stability}

To evaluate the chemical stability, gibberellic acid, L-tryptophan, and selected salts $(0.1 \mathrm{~g})$ were dissolved in $50 \mathrm{~cm}^{3}$ of water and heated at $80{ }^{\circ} \mathrm{C}$ for 2 days. The solvent was then evaporated using a rotary evaporator. The obtained compounds were dried using a vacuum dryer at $60{ }^{\circ} \mathrm{C}$ for $24 \mathrm{~h}$. Changes in the structure of the compounds were determined on the basis of NMR spectra analysis.

\section{Vase life of the leaves of C. majalis}

Healthy leaves of $C$. majalis L. without mechanical damage were collected early in the morning from plants growing on a bed at the University of Life Sciences in Poznan. The leaves were conditioned in aqueous solutions of gibberellic acid $\left(\mathrm{GA}_{3}\right)$ and quaternary ammonium salts with the gibberellate anion at concentrations of 50 and $100 \mathrm{ppm}$ and in aqueous solutions of L-tryptophan (Trp) and tetrapentylammonium L-tryptophanate at concentrations of $0.5,1.0$, 50 , and $100 \mathrm{ppm}$ for $4 \mathrm{~h}$ in a room with a temperature of $18-20{ }^{\circ} \mathrm{C}$. The leaves were then placed in distilled water. The control sample consisted of leaves from the beginning of the experiment placed in distilled water. The post-harvest stability of leaves was determined in a room with a temperature of $18-20^{\circ} \mathrm{C}$, a 12 -h photoperiod and fluorescent light with a quantum radiation intensity of $25 \mu \mathrm{mol} \mathrm{s}{ }^{-1} \mathrm{~m}^{-2}$, and the relative humidity of the air was maintained at $70 \%$. During the experiment, the water was changed twice a week.

Leaf longevity was determined in days. The loss of decorative values was determined by the moment of yellowing and/or wilting of $30 \%$ of the leaf blade area. After completing the experiment in which the post-harvest longevity of leaves was assessed after the application of $\mathrm{GA}_{3}$ and gibberellates, the content of chlorophyll $a+b$ and proteins in leaves was determined. The content of protein in the leaves was determined using the Bradford method [31]. During the assay, $2 \mathrm{~cm}^{3}$ of a solution of Coomassie Brilliant Blue G-250 (CBB) in $85 \%$ orthophosphoric acid was added to $100 \mathrm{~mm}^{3}$ of a diluted extract, with the extraction in a phosphoratepotassium buffer ( $\mathrm{pH} 7.0$ ). After $10 \mathrm{~min}$, the absorbance was measured at a wavelength of $595 \mathrm{~nm}$. The protein content was determined from a reference curve plotted for albumin.

The level of chlorophyll was determined following the method described in the literature after extraction with 
DMSO without tissue maceration [32]. Weighed portions $\left(100 \mathrm{mg}\right.$ ) were treated with $5 \mathrm{~cm}^{3}$ of DMSO and incubated in a water bath at $65{ }^{\circ} \mathrm{C}$ for $60 \mathrm{~min}$. The levels of chlorophyll in the obtained extracts were determined spectrophotometrically at a suitable wavelength. For chlorophyll $a$, the absorbance of the extract was measured at a wavelength of $663 \mathrm{~nm}$, and for chlorophyll $b$, it was measured at $645 \mathrm{~nm}$. The content of the pigments was calculated by means of Arnon's formulae and given in $\mathrm{mg} \mathrm{g}^{-1} \mathrm{FW}$ [33].

The experiment in which gibberellic acid and ammonium salts with gibberellate anion was used consisted of $11 \mathrm{com}$ binations with 3 replicates, with 5 leaves in each, whereas the experiment in which L-tryptophan and tetrapentylammonium L-tryptophanate were used consisted of 9 combinations and the same number of repetitions and leaves in each of them. One combination (conditioning solution $\times$ concentration) included 15 leaves.

The experimental results were subjected to a two-factor analysis of variance. The means were grouped using the Newman-Keuls test at the level of significance $\alpha=0.05$. The Statistica 13.1 program was used.

Acknowledgements This work was supported by Polish Ministry of Science and Higher Education, as a research project under the program "Diamond Grant" (Grant no. DI2016018446).

Open Access This article is licensed under a Creative Commons Attribution 4.0 International License, which permits use, sharing, adaptation, distribution and reproduction in any medium or format, as long as you give appropriate credit to the original author(s) and the source, provide a link to the Creative Commons licence, and indicate if changes were made. The images or other third party material in this article are included in the article's Creative Commons licence, unless indicated otherwise in a credit line to the material. If material is not included in the article's Creative Commons licence and your intended use is not permitted by statutory regulation or exceeds the permitted use, you will need to obtain permission directly from the copyright holder. To view a copy of this licence, visit http://creativecommons.org/licenses/by/4.0/.

\section{References}

1. Rubinstein B (2000) Plant Mol Biol 4:303

2. Bowyer MC, Wills RBH (2003) Delaying postharvest senescence of cut flowers using nitric oxide. A report for the rural industries research and development. RIRDC, Barton

3. Lawton KA, Raghothama KG, Goldsbrough PB, Woodson WR (1990) Plant Physiol 93:1370

4. Shibuya K (2012) J Jpn Soc Hortic Sci 81:140

5. Musembi NN, Adeya N, Murigi WW (2012) J Hortic Sci Biotechnol 87:419
6. Musembi NN, Hutchinson MJ, Waithaka K (2013) Acta Hortic 9:47

7. Gan S (2010) The hormonal regulation of senescence. In: Davies PJ (ed) Plant hormones: biosynthesis, signal transduction, action!. Springer, Heidelberg, London, New York, Dordrecht, p 597

8. Cottrel TE, Wood BW, Ni X (2009) Environ Entomol 38:411

9. Janowska B, Stanecka A (2011) Acta Agrobot 64:91

10. Janowska B, Stanecka A, Czarnecka B (2012) Acta Sci Pol Hortorum Cultus 11:121

11. Wang Y, Zhao J, Lu W, Deng D (2017) Plant Cell Rep 36:391

12. Chen S-Y, Kuo S-R, Chien C-T (2008) Tree Physiol 28:1431

13. Urbanova T, Leubner-Metzger G (2016) Gibberellins and seed germination. In: Hedden P, Thomas SG (eds) The gibberellins. Annual plant reviews, vol 49. Wiley, USA, p 253

14. Saeed T, Hassan I, Abbasi NA, Jilani G (2014) Plant Growth Regul 72:89

15. Camara MC, Vanderberghe LPS, Rodrigues C, de Oliviera J, Faulds C, Bertrand E, Soccol CR (2018) Planta 248:1049

16. Miceli A, Moncada A, Sabatino L, Vetrano F (2019) Agronomy 9:382

17. Shiu WY, Ma KC, Mackay D, Seiber JN, Wauchope RD (1990) Rev Environ Contam Toxicol 116:15

18. Nakhooda M, Watt PM, Mycock D (2011) Plant Growth Regul 65:263

19. Todorovski T, Fedorova M, Hoffmann R (2011) J Mass Spectrom 46:1030

20. Niemann T, Zaitsau D, Strate A, Villinger A, Ludwig R (2018) Sci Rep 8:14753

21. Yang R, Xiao C-F, Guo Y-F, Ye M, Lin J (2018) Mater Sci Eng C 91:475

22. Patron L, Marinescu G, Culita D, Diamandescu L, Carp O (2008) J Therm Anal Calorim 91:627

23. Freemantle M (2009) An introduction to ionic liquids. Royal Society of Chemistry, Cambridge

24. Palmer GH (1974) J Inst Brew 80:13

25. Salman RS, Derwish GAW, Al-Salih SS (1986) Spectrochim Acta A $42: 405$

26. Rabiza-Świder J, Skutnik E, Wachowicz M, Łukaszewska AJ (2004) Acta Sci Pol Hortorum Cultus 3:67

27. Joyce MD, Jennings MC, Santiago CN, Fletcher MH, Wuest WM, Minbiole KPC (2016) J Antibiot 69:344

28. Czuryszkiewicz D, Maćkowiak A, Marcinkowska K, Borkowski A, Chrzanowski Ł, Pernak J (2019) ChemPlusChem 84:268

29. Kaczmarek DK, Rzemieniecki T, Marcinkowska K, Pernak J (2019) J Ind Eng Chem 78:440

30. Vogel AI, Furniss BS (1984) Vogel's textbook of practical organic chemistry, 4th edn. Wiley, London

31. Bradford MMA (1976) Anal Biochem 72:248

32. Hiscox JD, Israelstam GF (1979) Can J Bot 57:1332

33. Arnon DI (1949) Plant Physiol 24:1

Publisher's Note Springer Nature remains neutral with regard to jurisdictional claims in published maps and institutional affiliations. 